\title{
Badania nieniszczące: historia, stan obecny i perspektywy rozwoju
}

\author{
Non-destructive testing: history, \\ current state and development directions
}

\section{Streszczenie}

W artykule w skrócie przedstawiono historię, stan obecny i perspektywy rozwoju badań nieniszczących. Wskazano na ich wpływ na poprawę bezpieczeństwa urządzeń, środowiska i ludzi. Zasygnalizowano, że badania nieniszczące można podzielić na metody: testowania (pomiaru), rozpoznawanie, gromadzenia danych, obróbki informacji i i podejmowania decyzji o stanie badanego obiektu. Wszystkie wymienione operacje podlegają ciągłemu rozwojowi.

\section{Historia badań nieniszczących}

Badania nieniszczące towarzyszą ludziom od zawsze. Gdy pierwotny człowiek wybierał kij do walki ze zwierzętami, badał jego stan, posługując się zmysłami. Dla niego istotne było upewnienie się, że kij nie ulegnie złamaniu w czasie walki. Do badań nieniszczących można zaliczyć monitoring środowiska naturalnego oraz nawet najprymitywniejsze sposoby oceny stanu zdrowia. Za początek badań nieniszczących (ang. Non Destructive Testing - NDT) w obecnej postaci można uznać odkrycie i zastosowanie promieniowania X przez Wilhelma Conrada Roentgena w 1895 r. Następnym ważnym krokiem w rozwoju badań nieniszczących było użycie w 1893 r. ultradźwięków. Kolejnymi etapami rozwoju było wykorzystanie do badań nieniszczących metod elektromagnetycznych, a mianowicie prądów

Dr hab. inż. Tomasz Chady, prof. dr inż. Ryszard Sikora - Zachodniopomorski Uniwersytet Technologiczny, Szczecin. wirowych, magnetycznego strumienia rozproszenia, szumów Barkhausena, przepływu prądu (tomografia impedancyjna) oraz metod z wykorzystaniem fal elektromagnetycznych o wysokich częstotliwościach, np. mikrofal. Obecnie, w związku z koniecznością testowania kompozytów, do badań nieniszczących coraz częściej wykorzystywana jest technika terahercowa. Rozwijana jest też metoda termograficzna polegająca na wykrywaniu wad przez obserwację zmian temperatury powierzchni badanego obiektu. Pewien fragment rozwoju badań nieniszczących przedstawił prof. Donald O. Thompson w pracy [1] na konferencji QNDE w 2009 r. Praca została opublikowana przez American Institute of Physics w 2010 r. Autor stwierdził, że formalnie NDT w USA miały swój początek w czasie II wojny światowej. Ze względu na to, że autor tej pracy był związany $z$ amerykańskim lotnictwem, podane przez niego przykłady dotyczą głównie tej dziedziny. W pracy wykazano, że NDT w USA rozwinęły się w czasie II wojny światowej, ponieważ konieczne było zapewnienie absolutnej niezawodności środków bojowych. W początkowej 
fazie NDT miały ściśle przemysłowy (aplikacyjny) charakter bez widocznego udziału badań naukowych. Po II wojnie światowej zasadniczą rolę w rozwoju NDT w USA odegrały: NASA, Departament Obrony, Komisja Energii Atomowej i Departament Energii. W dalszym ciągu artykułu autorzy przedstawiają proces przechodzenia od jakościowej oceny wad (NDT) do pełnej oceny ilościowej (ang. Non Destructive Evaluation - NDE). NDE umożliwia pełną identyfikację stanu struktur i występujących w nich niedoskonałości. Z identyfikacją wad wiąże się ich klasyfikacja do określonej kategorii. Autorzy zauważają, że obecnie coraz częściej jest stosowany ciągły monitoring badanych obiektów (ang. Structural Helth Monitoring - SHM). Umożliwia on stałą kontrolę stanu testowanego elementu i wykrywanie wad na wstępnym etapie powstawania, zanim przekroczą one dopuszczalne wymiary.

Podkreśla się również duże znaczenie narzędzi symulacyjnych. Wśród głównych instytucji, które przyczyniły się do rozwoju badań w tym zakresie, autorzy wymieniają: CEA - Commission for Atomic Energy and Alternative Energies, France, Chalmers University of Technology, CNDE - Center for Nondestructive Evaluation - lowa State University, IZFP - Fraunhofer-Institut für Zerstörungsfreie Prüfverfahren, Saarbrucken and University of Kassel. W tym zestawieniu skoncentrowano się jedynie na symulatorach układów ultradźwiękowych i pominięto osiągnięcia czołowych ośrodków badawczych z Japonii, Rosji czy Wielkiej Brytanii. W wymienionych krajach istnieje rozwinięty przemysł kosmiczny i nuklearny, co wydatnie przyczynia się do rozwoju NDT. Należy też podkreślić ważną rolę, jaką w badaniach NDT odgrywają zastosowania w biologii, medycynie i ochronie środowiska.

Drugi artykuł, który został przedstawiony na QNDE 2009 i opublikowany w AIP, jest poświęcony pewnemu wycinkowi tematyki badań nieniszczących [2]. Autor przedstawił w nim metody elektromagnetyczne i metody sprzężone z nimi. Pominął jednak metodę przepływową (tomografię impedancyjną), strumienia rozproszenia i szumów Barkhausena. Zwrócił uwagę na szerokie możliwości, jakie daje wykorzystanie fal terahercowych. Jednak błędnie określił ich pasmo jako obejmujące zakres częstotliwości od $3 \mathrm{GHz}$ do $3 \mathrm{THz}$. W rzeczywistości pasmo to zawiera się w granicach od $300 \mathrm{GHz}$ do $10 \mathrm{THz}$. Badania nad wykorzystaniem metody terahercowej do inspekcji kompozytów prowadzone są również w Zachodniopomorskim Uniwersytecie Technologicznym [3].

Trzecia praca $z$ tej samej konferencji poświęcona jest badaniom konstrukcji betonowych [4]. Grupa FOR 384 działała w Niemczech w latach $2001 \div 2007$ i brało w niej udział siedem instytucji z Niemiec. Celem prowadzonych przez nią badań było opracowanie i ocena metod wykrywania wad w betonach litych i spienionych. W badaniach posłużono się metodą ultradźwiękową. W pracy nie ujęto niestety tematyki badań konstrukcji żelazobetonowych metodami elektromagnetycznymi. Ze względu na znaczenie tego typu konstrukcji i postępujące procesy ich degradacji tematem tym zajmuje się obecnie wiele ośrodków badawczych, a w tym również grupa z Zachodniopomorskiego Uniwersytetu Technologicznego. Nieco inny punkt widzenia na roz-

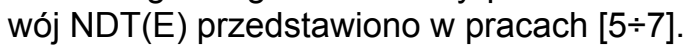

\section{Stan obecny}

Obecnie podstawową metodą badawczą stosowaną w NDT jest technika ultradźwiękowa [8]. Metoda ultradźwiękowa stanowi ponad $50 \%$ wszystkich metod stosowanych obecnie w badaniach nieniszczących. Metody elektromagnetyczne stanowią w tym ok. $20 \%$. Do metod elektromagnetycznych zaliczamy następujące metody: przepływową (tomografię impedancyjną), strumienia rozproszonego, szumów Barkhausena, prądów wirowych i mikrofalową. Do tej kategorii należy zaliczyć też metodę terahercową. Ważną rolę odgrywają też metody wykorzystujące wysokoczęstotliwościową część widma fal elektromagnetycznych, poczynając od podczerwieni (termografia), a kończąc na promieniowaniu rentgenowskim. Metody te obejmują około $10 \%$ metod stosowanych w NDT. Są one na ogół droższe od innych metod, mają jednak bardzo ważną zaletę polegającą na prostej interpretacji wyników, wysokiej czułości i dużej rozdzielczości. Umożliwiają wykrywanie nawet mikronowych wad. Odgrywają istotną rolę $\mathrm{w}$ diagnostyce medycznej. Jedynym problemem w zastosowaniach medycznych jest duża energia wprowadzana do badanego obiektu (organizmu) podczas badań. Wprowadzenie radiografii cyfrowej umożliwiło zmniejszenie dawki promieniowania jonizującego dzięki wyższej czułości detektorów, poprawę rozdzielczości (rozróżnialności) i ułatwiło przetwarzanie obrazów [7]. W przypadku obrazu analogowego (uzyskanego za pomocą błony) rozdzielczość w wielu przypadkach jest jeszcze ciągle większa niż obrazów uzyskanych za pomocą przetworników cyfrowych. Przetwarzanie obrazu analogowego jest jednak trudniejsze i mniej skuteczne niż cyfrowego z powodu konieczności jego wcześniejszej digitalizacji i wysokiego poziomu szumów, a także nieliniowej charakterystyki błon radiograficznych. Z tych powodów radiografia cyfrowa (z zastosowaniem przetworników bezpośrednich), jak i radiografia komputerowa (z zastosowaniem płyt obrazowych) staje się coraz bardziej popularna.

Duża liczba dostępnych metod inspekcji i w wielu przypadkach komplementarność danych uzyskiwanych z poszczególnych metod przyczyniła się do wykorzystania algorytmów fuzji danych w badaniach nieniszczących. Pozwala to na pełniejsze zobrazowanie badanych struktur i podwyższenie prawdopodobieństwa wykrycia defektów (ang. Probability of Detection - POD). Modelowanie POD [1], analiza statystyczna i algorytmy sztucznej inteligencji umożliwiają znaczącą poprawę niezawodności systemów NDT. 


\section{Perspektywy rozwoju NDT(E)}

Badania NDT(E) będą się rozwijać w kierunku doskonalenia i potanienia istniejących metod oraz poszukiwania nowych metod badawczych [9, 10]. Równolegle z tym szerzej będą stosowane układy SHM i fuzja danych. Wystąpi silniejsza integracja NDT(E) $z$ diagnostyką medyczną. Spowoduje to udoskonalenie systemów diagnostyki w obu obszarach zastosowań. W wielu przypadkach występuje zatarcie różnic między diagnostyką techniczną i medyczną. Jest to spowodowane tym, że coraz szerzej stosowane są różnorakie implanty, które w istocie są urządzeniami technicznymi, pełniąc jednak rolę medyczną. Szczególną rolę będą odgrywać implanty wykorzystywane w układzie krwionośnym i centralnym układzie nerwowym. Należy się spodziewać szybszego rozwoju metody terahercowej, która może odegrać kluczową rolę $w$ badaniu materiałów kompozytowych [3]. Na tym tle budzi zdziwienie opinia niektórych ekspertów krajowych twierdzących, iż w przemyśle nie ma zapotrzebowania na testowanie materiałów kompozytowych. Już obecnie materiały kompozytowe stanowią bardzo ważny materiał konstrukcyjny. Całe kadłuby samolotów budowane są z materiałów kompozytowych. Łopatki elektrowni wiatrowych też są wykonywane z kompozytów. Kompozyty mają też ogromną perspektywę w grupie materiałów inteligentnych. Rozwój materiałów inteligentnych tworzonych na bazie kompozytów spowoduje szybki rozwój metod badawczych z wykorzystaniem SHM i fuzji danych. Jednak najważniejszym wyzwaniem będzie wykorzystanie sztucznej inteligencji w badaniach nieniszczących [11, 12]. Sztuczna inteligencja daje możliwość podejmowania jednoznacznych i powtarzalnych decyzji o stanie materiału i badanych obiektów. Autorzy realizowali projekt rozwojowy ISAR - Inteligentny System Analizy Radiogramów w latach 2009-2012 na zlecenie Narodowego Centrum Badań i Rozwoju. Celem systemu ISAR jest automatyzacja pracy operatora systemów radiografii cyfrowej. Podstawowymi operacjami realizowanymi $w$ systemie ISAR jest cyfryzacja radiogramu, wstępna filtracja obrazu, detekcja niezgodności, parametryzacja wykrytych obiektów, identyfikacja klasy niezgodności i podjęcie decyzji o istnieniu wady [12]. W tym systemie ważną rolę odgrywa baza danych zawierająca wcześniej wykryte wady opisane za pomocą odpowiednio dobranych parametrów, system porównujący cechy analizowanego obiektu na radiogramie z cechami wad zebranymi w bazie danych oraz system decyzyjny. Opracowany system pozwala na uzyskanie poprawnej decyzji w przypadku $70 \div 99 \%$ wykrytych niezgodności. Na bazie przedstawionego systemu prof. R. Sikora zaproponował system do automatycznego wykrywania raka piersi. Na współpracę w proponowanym projekcie zgodził się prof. Jan Lubiński, wybitny polski genetyk. Projekt został zgłoszony w ramach programu badań podstawowych Symfonia. Niezależnie od tego, czy ten projekt zostanie zrealizowany, przedstawiona idea polegająca na wykorzystaniu sztucznej inteligencji w NDT będzie stanowić jeden z głównych kierunków rozwoju badań nieniszczących.

\section{Literatura}

[1] Thompson D.O.: Evolution of QNDE'S Core Interdisciplinary Science and Engineering Base, Review of Progress in QNDE, 2009, Vol.32 A, s. 3-25.

[2] Ringermacher H. I.: NDE: Surfing the Electromagnetic Spectrum, Review of Progress in QNDE,2009, Vol.32 A, s. 29-46.

[3] Chady T., Gorący K., Łopato P.: Image and signal processing algorithms for THZ imaging of composite materials, Review of Progress in Quantitative Nondestructive Evaluation. Vol. 29, 2010, AIP, s. 766-773.

[4] H. Wiggenkhauser and H.W. Reinhardt, "NDT in Civil Engineering: Experience and Results of the FOR 384 Research Group" , Review of Progress in QNDE,2009, Vol.32 A

[5] Forney D.M.: USAF NDE program - Requirement for technology Transaction Technical Report AFML-TR-TI-44, July 18, 1975 - September 1976, s. 220.

[6] [6] Raj B. and Venkatraman B.:NDE Measurements for Understanding of Performance: A Few Case Studies on Engineering Components, Human Health and Cultural Heritage, Review of Progress in QNDE, 2011, Vol.32 A, s. 7-17.

[7] Ewert U.: Advances in Digital Industrial Radiology - New Application Areas Beyond Film Radiography", Review of Progress in QNDE, 2011, Vol.32 A, s. 8-32. 